\title{
Paradiplomasi Menuju Kota Dunia: Studi Kasus Pemerintah Kota Makassar
}

\author{
Laode Muhamad Fathun \\ Universitas Muhammadiyah Yogyakarta
}

\begin{abstract}
Abstrak
Transformasi model tata kelola pemerintahan dari sentralistik menjadi desentralistik membuka peran pemerintah daerah untuk turut andil dalam memajukan kepentingan nasional Indonesia. Lahirnya Undang-Undang Otonomi Daerah sebagai otoritas hukum menjadi legalitas pemerintah daerah untuk bergerak cepat dalam mengejar pembangunan dengan melihat sejumlah potensi yang mereka miliki. Peran pemerintah daerah yang kompleks ternyata bukan sekedar dalam menjadi aktor lokal saja akan tetapi bisa menjadi aktor hubungan internasional atau dikenal dengan 'paradiplomasi'. Implementasi hubungan internasional paradiplomasi misalnya melakukan kerjasama investasi asing untuk menarik investor menanamkan modalnya di daerah. Makassar merupakan salah satu kota yang telah mengimplementasikan paradiplomasi untuk membentuk smart city dalam rangka menciptakan tata kelola pemerintahan yang baik yang dicirikan oleh integritas, akuntabilitas, dan transparan. Program smart city di Makassar merupakan program strategis yang mendapat pujian dari sejumlah pihak seperti gubernur hingga menteri, bahkan Konsulat Amerika Serikat memberikan apresiasi terhadap program tersebut. Oleh karena itu, disebabkan oleh kemajuan dalam bidang teknologi informasi setiap kota dan kabupaten serta propinsi seharusnya menciptakan kota pintar berbasis teknologi informasi untuk menciptakan pelayanan publik yang lebih efisien dan inovatif.
\end{abstract}

Kata-kata Kunci: Transformasi model pemerintahan, paradiplomasi, investasi, hubungan internasional, smart city, teknologi informasi

\begin{abstract}
The transformation of governance from centralized to decentralized opens the role of local governments to contribute in advancing national interests. The birth of the Regional Autonomy Law as a legal framework for local governments to pursue development goals by looking at a number of potentials they have. The role of local governments is not only becoming a local actor but also an international actor known as 'paradiplomacy'. The example of paradiplomacy in international relations is initiating cooperation on foreign investment to attract foreign investors. Makassar is one city that has been implementing paradiplomacy to create a smart city in order to achive good governance characterized by integrity, accountability, and transparent. Smart city program in Makassar was a strategic program that won praise from a number of parties such as the governor up to ministers, even US Consulate gave an appreciation to the program. Therefore, due to the rapid progress of the information technology every single town and district as well as
\end{abstract}


province should create IT-based smart city to create a public service that is more efficient and innovative.

Keywords: Transformation of governance, paradiplomacy, investment, international relations, smart city, information technology

\section{Pendahuluan}

Isu hubungan internasional bergeser dari yang bersifat high politic seperti konflik dan perang yang cenderung mengedepankan hardpower ke isu-isu kerjasama (Rudi, 2003:2). Untuk menjamin hubungan kerjasama yang baik antar negara maka diperlukan cara sebagai sebuah proses dalam memperjuangkan kepentingan masing-masing. Komunikasi yang efektif merupakan salah satu faktor pendukung dalam hubungan kerjasama tersebut yang dalam disiplin ilmu Hubungan Internasional sering disebut dengan diplomasi. George Kennan (dalam Nicolson, 1974:4) mendefinisikan diplomasi sebagai "an art and international relations in a universal context." Kemudian Nicolson (1974:89) memperjelas definisi tentang diplomasi yaitu "(a) The management internal relation by means of negotiation, (b) The method by which these relation are adjusted and manage by ambassadors and envoys, (c) The business of art of the diplomatist, (d) Skill or address in the conduct of international intercourse and negotiation." Sejalan dengan pendapat tersebut diplomasi adalah "suatu cara komunikasi dengan pemilihan kata serta kalimat yang dilakukan berbagai pihak-pihak termasuk negosiasi antara wakil-wakil yang diakui untuk meraih kepentingan kita sendiri" (Partao, 2007:35). Jadi dapat disimpulkan bahwa diplomasi merupakan upaya negara melalui cara berkomunikasi yang baik dengan wakil-wakil yang terpilih untuk merebut kepentingan nasional dengan jalan damai.

Namun, pendefinisian diplomasi menurud ahli di atas merupakan diplomasi yang masih bersifat tradisonal atau masih menitik beratkan peran negara dan diplomat dengan cara-cara yang selalu resmi seperti perundingan dan negosiasi. Artinya, diplomasi konvensional ini masih sangat sentralistik dan high class, eksklusif, resmi, dan protokoler sehingga aktor diplomasi sangat terbatas dan masih bersifat diplomasi tingkat tinggi. Seiring perkembangan hubungan internasional yang semakin dinamis maka perkembangan diplomasi pun semakin maju atau yang lebih dikenal dengan diplomasi modern. 
Adanya globalisasi menjadikan format diplomasi tingkat tinggi berubah menjadi the foreign policy and non-central government yang mengacu pada diplomasi bukan bertumpu microdiplomacy. Artinya, aktor yang berperan berada di sub-sistem negara yakni pemerintah daerah atau yang dikenal dengan istilah 'paradiplomasi' (Mukti, 2013:2). Paradiplomasi memunculkan aktor-aktor non-tradisonal seperti kelompok, individu, organisasi dan sub-negara untuk mencapai kepentinganya masing-masing (Mellisen, 1999:xv; Meerts, 2009:90; Stefan, 2009:1-2; dan David, 2008:34). Dengan dasar pemikiran seperti itu paradiplomasi lahir sebagai legitimasi bagi munculnya aktor-aktor baru dalam hubungan internasional. Dengan demikian, diversifikasi peran aktor diplomasi memberi kesempatan kepada pemerintah daerah untuk terlibat langsung dalam hubungan internasional seperti investasi, perdagangan, tanpa harus aktif dalam perkara tertentu untuk melapor kepada pemerintah pusat.

\section{'Paradiplomacy' dalam kerangka otonomi daerah}

Investasi asing langsung (Foreign Direct Investment) merupakan salah satu bentuk investasi asing baik berupa penanaman modal maupun pendirian industri atau pabrik ke daerah-daerah tertentu di Indonesia. Investasi asing langsung adalah investasi di suatu negara yang berasal dari negara- negara melalui perusahaan-perusahaan multinasional yang dimilki oleh pihak swasta (Todaro, 2000:250). Sementara itu, Fathonah (2010:163) mengatakan bahwa investasi asing langsung adalah suatu bentuk penanaman modal asing ke dalam aktifitas perekonomian negara lain. Investasi asing langsung biasanya berbentuk fisik misalnya pembangunan pabrik dan melibatkan partisipasi perusahaan. Selain itu, penanaman modal melalui investasi asing langsung ini juga bersifat jangka panjang.

Hal-hal yang berkaitan erat dengan investasi asing langsung memiliki keterkaitan langsung dengan kebijakan otonomi daerah dimana dalam proses pengelolaan investasi maka para investor akan berhadapan langsung dengan kebijakan yang ada di daerah tersebut sehingga akan berdampak positif bagi proses pembangunan berkelanjutan di Indonesia. Kebanyakan pelaku investasi asing adalah perusahaan multinasional (MNC). Kehadiran MNC sangat mempengaruhi keadaan ekonomi suatu negara, terutama bagi negara dunia ketiga di mana MNC merupakan salah satu sumber modal yang penting bagi pembangunan ekonominya (Dougherty \& Pfahzgraff, 1990:255). Sejak diterbitkannya Undang- 
Undang Tentang Penanaman Modal Asing Nomor 1 Tahun 1967, banyak investor asing dan MNC mulai diundang ke Indonesia. Di tahun yang sama tepatnya bulan April pemerintah Indonesia memberikan izin kepada PT. Freeport Indonesia sebagai MNC pertama yang beroperasi di Indonesia(Kuncoro, 1997:291).

Sasaran investasi di Indonesia pada umumnya diarahkan pada beberapa sektor kehidupan misalnya industri, pertambangan, teknologi dan lain-lain. Oleh karena itu, dengan dukungan besarnya potensi sumber daya alam yang dimiliki oleh Indonesia maka dapat menarik minat para investor untuk melakukan investasi. Investasi kini sudah merambah ke daerah-daerah yang memiliki potensi sumber daya alam yang sangat potensial. Setiap pemerintah daerah, dengan demikian, mulai berperan aktif dalam memanfaatkan potensi tersebut untuk meningkatkan pembangunannya. Hal tersebut dapat dianggap sebagai perpanjangan tangan pemerintah pusat dalam memajukan ekonomi masyarakat.

Untuk melegalkan peran pemerintah daerah dalam memanfaatkan potensi di wilayahnya maka pemerintah merumuskan Undang-Undang Nomor 32 Tahun 2004 tentang Pemerintahan Daerah yang kemudian direvisi menjadi Undang-Undang Nomor 12 Tahun 2008 yang kemudian direvisi lagi menjadi Undang-Undang Nomor 23 Tahun 2014. Munculnya aturan tersebut memberikan wewenang kepada sejumlah daerah secara semi-otonom dalam rangka mendorong pembangunan di daerah. Oleh karena itu, melalui otonomi daerah kemandirian dalam menjalankan pembangunan sesuai dengan kapasitas dan kebutuhan daerah diharapkan dapat dilakukan dengan lebih efektif dan efisien (Imawan, 2006:11).

Pemerintahan yang desentralistik dapat mendorong pelayanan yang lebih maksimal kepada masyarakat setempat. Hal ini dikarenakan pihak yang mengetahui secara pasti karakter sebuah daerah adalah pemerintah daerah itu sendiri. Kinerja pemerintah daerah yang maksimal tentu berperan penting dalam pemanfaatan potensi daerah termasuk dalam melakukan kerjasama dengan pihak lainya baik domestik maupun internasional dalam level G to G, G to NGOs, G to B dan seterusnya yang erat kaitanya dengan penanaman modal asing. Dalam hal ini investasi asing yang dimaksudkan adalah investasi asing dalam bentuk transfer teknologi dalam membentuk tata kelola pemerintahan kota yang berbasis pada teknologi informasi. Artinya konsep smart city merupakan bentuk investasi sebagai variabel penarik atau variabel pengaruh terhadap munculnya investasi bidang lainya seperti investasi di bidang ekonomi perdagangan, pariwisata, budaya, kuliner dan lain-lain. Investasi-investasi 
dari beberapa bidang tersebut sangat penting untuk mendorong pembangunan ekonomi. Ada empat jenis kegiatan ekonomi bisnis yaitu promosi perdagangan dengan fokus utama tidak eksklusif pada penanganan kegiatan untuk meningkatkan ekspor; promosi peluang investasi terutama dikhususkan pada investasi dalam negeri tetapi tidak dari negara-negara lain; menarik masuk teknologi yang memadai; dan pengelolaan bantuan ekonomi yang perlu untuk negara-negara berkembang (Djelantik, 2008:230).

Jadi dapat disimpulkan bahwa kerjasama internasional dalam bentuk investasi asing yang dilakukan oleh negara atau perusahaan swasta dalam kerangka otonomi daerah sangat berpeluang besar untuk memajukan daerah. Melalui pengelolaan secara bersama antara pemerintah daerah sebagai penyedia sumberdaya alam dan negara lain atau perusahaan sebagai penyedia modal dan teknologi, maka kemajuan pembangunan daerah akan semakin meningkat. Oleh sebab itu, investasi asing merupakan wujud hubungan timbal balik antara pemerintah daerah dan investor asing dalam kerangka otonomi daerah.

\section{Pemerintah daerah sebagai aktor diplomasi}

Pada hakekatnya pelayanan pemerintah yang baik terhadap rakyatnya baik itu pemerintah pusat maupun pemerintah daerah sangat berpengaruh terhadap kinerja dan kredibilitas pemerintah sebagai pemegang kekuasaan dan pengambil kebijakan. Menurut Rasyid (1997:100), "paradigma pemerintahan harus didasarkan pada asumsi bahwa pemerintahan dalam jangkauan masyarakat menitikberatkan pada bentuk pelayanan yang diberikan menjadi lebih cepat, hemat, murah, responsif, akomodatif, inovatif serta produktif. Diperlukan payung hukum sebagai legalitas pemekaran daerah yang diberi tugas untuk mengelola daerah otonom.

Seperti yang sudah di tuliskan sebelumnya pemerintah Indonesia telah memiliki undang-undang otonomi daerah yang menyatakan bahwa daerah sebagai bagian sub-sistem dari Indonesia dan perpanjangan tangan pemerintah pusat berhak dan legal untuk mengurusi daerahnya sendiri dengan memanfaatkan potensinya. Oleh sebab itu, dalam konsep tata pemerintahan daerah (local government) disebutkan bahwa otonomi diartikan sebagai mengurus dan mengatur rumah tangganya sendiri. Wewenang tersebut dimaksudkan supaya tercapai peningkatan pelayanan dan kesejahteraan masyarakat, pengembangan kehidupan demokratis, keadilan pemerataan dan pemberdayaan masyarakat, yang 
menuju kepada tingkat kemandirian masyarakat daerah serta hubungan harmonis antara pusat dan daerah serta antar daerah (Suryaningrat, 1981:32).

Namun, peraturan-peraturan tentang otonomi daerah belum berbicara masalah teknis kerjasama yang bisa dilakukan oleh daerah. Dalam aturan lainya untuk kembali melegalkan dan mempermudah dan menyaring diplomat-diplomat baru (paradiplomasi) ini munculah beberapa aturan hukum lainya seperti Undang-Undang Nomor 37 Tahun 1999 tentang Tata Cara Hubungan Luar Negeri, Undang-Undang Nomor 24 Tahun 2000 tentang Perjanjian Internasional, Peraturan Menlu RI Nomor 09/A/KP/XII/2006, Permendag Nomor 3 Tahun 2008, Permendag Nomor 74 Tahun 2012, merupakan sejumlah aturan teknis legal bagi pemerintah daerah walaupun tidak bisa secara langsung diimplementasikan karena harus melalui Kementerian Luar Negeri sebagai koordinator hubungan luar negeri (open door policy), Kementerian Dalam Negeri, Kementerian Hukum dan HAM, serta MPR.

Akan tetapi, seberapapun besarnya wewenang pemerintah daerah yang diamanatkan oleh konstitusi tetap saja pemerintah daerah menjadi sub-sistem negara. Dalam hal ini, pemerintah daerah sebagai pelaku hubungan kerjasama internasional dalam bentuk investasi asing hanya bisa sampai pada panandatangan MoU atau Letter of Intent. Itu artinya dalam kesepakan-kesepakan perjanjian yang lebih tinggi seperti perjanjian, traktat, atau konvensi menjadi tanggung jawab pemerintah pusat. Dengan demikian sinergi antara pemerintah daerah dan pemerintah pusat dalam mengelola kerjasama luar negeri pemerintah pusat - dalam hal ini Kementrian Lura Negeri - mempunyai wewenang untuk: memadukan seluruh potensi kerjasama daerah agar tercipta sinergi dalam penyelenggaraan hubungan dan kerjasama luar negeri; mencari terobosan baru (inisiator); menyediakan data yang diperlukan (informator); mencari mitra kerja di luar negeri; mempromosikan potensi daerah di luar negeri (promotor); memfasilitasi penyelenggaraan hubungan kerjasama luar negeri (fasilitator); dan memberi perlindungan kepada daerah (protector) (Arsyad dan Masrie, 2010:8).

Walaupun tanggung jawab pemerintah daerah sangat besar akan tetapi tujuan dari pemerintah pusat dalam membatasi kewenangan tersebut agar pemerintah daerah bisa menyamai atau mendominasi peran negara misalnya terkait investasi asing di daerah. Undang-Undang Nomor 23 Tahun 2014 Pasal 10 Ayat 1 menerangkan bahwa pemerintah pusat memiliki kekuasaan absolut dalam bidang politik luar negeri, 
pertahanan, keamanan, yustisi, moneter dan fiskal nasional, serta agama. Terkait implementasi otonomi daerah, Pasal 7 Ayat 1 Undang-Undang tersebut menyatakan pemerintah pusat hanya melakukan pembinaan dan pengawasan terhadap penyelanggaraan pemerintahan daerah, sementara dalam berbagai bidang tersebut pemerintah daerah tidak memiliki wewenang.

Akan tetapi, pemerintahan daerah harus mengarahkan pemerintahanya pada sejumlah hal yakni: transformasi diri dari bureaucratic monopolistic government menjadi entrepreneurial-competitive government, pemerintahan yang 'cuek-bebal' menjadi customers -driven government dan accountable government. Osborne (dalam Kertajaya \& Yuswohady, 2005:4-5), menyebut pemerintahan seperti ini adalah "put the costumers in the driver 's seat". Di samping itu, pemerintah daerah perlu membangun pemerintahan berwawasan global atau global-cosmopolite orientation. Pemerintahan berwawasan global dilaksanakan dengan membangun konsep 3C versi Moss Kanter yakni: Concept yakni pemerintah daerah harus punya ide inovatif dalam mempromosikan daerahnya, Competence yakni pemerintah daerah harus berani memposisikan diri sebagai produsen yang memiliki quality, cost and delivery, dan Connection yakni pemerintah daerah harus membangun networking sebanyak mungkin baik dalam negeri maupun luar negeri (Kertajaya \& Yuswohady, 2005:4-5).

Meskipun demikian, otonomi daerah mengandung kontradiksi internal. Dengan wewenang yang diberikan undang-undang pemerintah daerah menggunakan kekuasaan untuk menguras habis uang rakyat untuk memperkaya diri sendiri dan melakukan korupsi selama berkuasa, sehingga menciptakan raja-raja kecil di daerah yang memiliki otoritas yang tidak bisa dibendung dan membuat daerah justru semakin rusak dan rencana pembangunan buttom-up pasti dipastikan gagal total atau demokrasi lipstik dan menikmati 'mastubrasi politik' (Surwandono, 2014:40). Oleh sebab itu, butuh kesadaran mutlak dari semua elemen masyarakat dan pemerintah baik pusat maupun daerah untuk saling mendukung menciptakan Indonesia yang sejahtera adil dan makmur seperti yang diamanatkan dalam konstitusi.

\section{Paradiplomasi: Studi kasus Makassar menuju smart city}

Makassar sebagai salah satu kota gerbang ekonomi Indonesia di bagian timur tentunya membutuhkan suntikan dana agar bisa lebih cepat memaksimalkan pembangunan. Komitmen Pemerintah Kota Makassar 
untuk menggenjot pembangunan cukup tinggi. Satu jam setelah dilantik menjadi walikota Makassar, Mohammad Ramdhan Pomanto menandatangani MoU bersama Chief Executif Microsoft dalam membangun dan mengintegrasikan Makassar dengan daerah lainnya dalam bentuk 'Smart City' atau 'kota pintar' ( Antara News, 2014). Konsep smart 'kota pintar' merupakan sebuah wilayah berbasis teknologi dan sudah diterapkan di Denmark dan Korea Selatan. Program ini langsung menyita perhatian sejumlah negara asing untuk mendukung pembentukan 'kota pintar'. Tekom Indonesia, Bank BRI, PT. Nusantara Infrastructure Tbk, PT. Margautama Nusantara adalah sejumlah perusahaan dalam negeri yang siap mensukseskan program tersebut (Makassar Terkini, 2014). Tidak berhenti sampai di situ saja, pada 28 Mei 2014 walikota Makassar menindaklanjuti MoU sebelumnya dengan melakukan teleconference dengan presiden Microsoft untuk membantu Makassar menciptakan 'kota pintar' (Celebes Online, 2014).

Konsep smart city merupakan sebuah bentuk strategi kebijakan yang diterapkan untuk menjawab ekpektasi masyarakat dengan semakin majunya dunia oleh teknologi informasi. Dengan tuntutan itu, masyarakat memiliki obsesi untuk menikmati kota yang bisa melayani dengan cepat, tepat dan efisien. Gagasan kota berbasis smart city merupakan keinginan kota untuk lebih maju dalam menjawab tantangan jaman. Telkom Indonesia dalam program 'Smart City Solution: Telkom Solution for Indonesia Smart City' membagi sembilan kategori smart city: Smart Energy yakni terpenuhinya sistem penyimpanan dan penggunaan sumber energi secara efisien; Smart Building yakni penerapan tata bangunan yang cerdas, hemat energi (green building), sistem otomatisasi dan menggunakan Advance HVAC (Heating Ventilation \& Air Conditioning); Smart Mobility yakni penggunaan sistem manajemen lalu lintas yang canggih, manajemen parkir dan multimodel moda transportasi; Smart Technology yakni terwujud nya seamless connectivity termasuk 4G, Wi-fi, superbroadband, 1 GB/s download, Augmented Reality, LBS, dan GPS; Smart Infrastructure yakni penggunaan manajemen sensor yang terintegrasi; Smart Governance $\mathcal{E}$ Education yakni terbentuknya system $e$-Goverment, e-Education dan solusi disaster management; smart health care yakni tersedianya e-Health, $m$-Health dan peralatan media yang cerdas dan saling terkoneksi; Smart Citizen yakni timbulnya kesadaran untuk melakukan kebiasaan atau budaya baru yang erat hubungannya dengan sistem transportasi berbasis Go Green untuk menjalani gaya hidup sehat; dan Smart Security yakni terciptanya jaminan pengawasan, biometrik, model pencegahan untuk berbagai 
tindak kejahatan dan antisipasi bencana mengoptimalkan pelayanan pemerintahan kota sehingga memungkinkan optimalisasi sumber daya (energi, air, gas, tata ruang kota) untuk meningkatkan hubungan antar warga, termasuk untuk memberikan kemudahan aktivitas bisnis dan pariwisata.

Tawaran solusi membentuk smart city oleh Telkom adalah setiap kota memiliki: City Command Center sebagai pusat pengendali informasi dan untuk menginstruksikan pada instansi terkait; Urban CCTV Surveillance sebagai sebagai alat safe city untuk mendeteksi lokasi yang rawan kriminalitas; Decision Support System berkaitan dengan pengambilan keputusan pemerintah berbasis data akurat; Panic Button sebagai aplikasi yang tersedia di smartphone untuk memberitahu kepanikan terhadap suatu kondisi tertentu; Citizen Public Portal sebagai penyedia layanan bagi masyarakat terhadap pelayanan pemerintah yang efisien; Machine to Machine (M2M) sebagai aplikasi untuk menghubungakan Payment, Tracking, dan Energy Managemen; City Digital Media yakni media pemerintah yang menghubungkan dengan masyarakat baik dalam media cetak maupun elektronik; City Apps yakni aplikasi yang mendukung program-program pemerintah seperti e-puskesmas, $e$ kelurahan, SPGDT (Sistem Penanggulangan Gawat Darurat Terpadu), dan e-Lapor (pengaduan dari masyarakat); Immersive Telepresence yakni layanan media virtual bagi penghubung antar pemerintah dan masyarakatnya seolah dalam satu ruang dan waktu yang sama; serta Social Media Analytic yakni media yang memberikan kebebasan bagi publik untuk memberi saran atau opini terhadap pelayanan pemerintah.

Dalam upaya tersebut Pemerintah Kota Makassar menciptakan pelayanan publik berbasis teknologi informasi. 42 SKPD telah di integrasikan untuk menciptakan pelayan yang lebih efisien kepada masyarakat. Pada prakteknya seperti $e$-KTP, e- karcis, e-office, e-dokter, dan merencanakan pembuatan sebuah smartphone yang bisa mendeteksi arah jalan macet, keadaan situasi kota dan keamanan kota dan lain-lain. Tentunya program ini sangat baik sebagai langkah awal mencoba membuktikan slogan Makassar sebelumnya yakni menjadi 'smart city'.

Program ini juga menjadi salah satu langkah positif untuk mendukung Indonesia sebagai Negara poros maritim dunia sebab Bappenas merencanakan pembangunan tol laut di Makassar. Dengan demikian, program ini akan sinergis, karena tol laut akan menjadi tempat singgah kapal-kapal dagang asing, kargo, dengan smart city menjadi daya tarik yang menjadikan Makassar sebagai sebuah kota megapolitan di 
masa depan. Oleh karena itu, Makassar sebagai smart city bisa menyumbangkan devisa negara potensial. Hal ini sudah dibuktikan sejumlah mahasiswa Jepang yang melakukan studi kelayakan di Makassar tentang tata ruang pesisir laut. Dalam menggaungkan smart city ini pun walikota Makassar sudah menjelaskan ketika menghadiri konfrensi World City Summit di Universitas Osaka Jepang di hadapan para walikota dunia. Bahkan Profesor Weibe Bijker terkesan dengan prospek pembangunan di Makassar. Pakar tata ruang internasional tersebut mengatakan terkagumkagum dengan visi Makassar menjadi kota dunia seperti kota Bilbao di Spanyol.

Kepala Dinas Informatika Kota Makassar Ismuounandar mengatakan bahwa Pemerintah Kota Makassar akan memasang 153 kamera CCTV yang tentunya akan digunakan sebagai alat pemantau keadaan kota. Untuk sementara pemasangan CCTV di Kota Makassar baru di gunakan berbagai traffic light untuk memantau sejumlah arus lalu lintas. Menurutnya, lahirnya konsep smart city adalah sebuah terobosan baru untuk menuju kota cerdas berbasis teknologi informasi. Oleh sebab itu, diasumsikan bahwa pembentukan smart city akan menyokong tiga pilar utama yakni pengelolaan kota secara inovatif, efisien dan transparan serta akuntabel. Pembentukan smart city akan mendukung pola hidup masyarakat yang berkelanjutan dengan semakin majunya teknologi informasi sebagai bagian dari kemajuan globalisasi yang secara positif bisa di gunakan untuk lebih mencerdaskan kehidupan masyarakat serta kemudahan dan memunculkan benih-benih investasi yang berkembang baik yang datang dari investot dari dalam negeri maupun investor dari luar negeri.

Program ini merupakan sebuah terobosan yang mendapat apresiasi positif dari Kementrian Komunikasi dan Informatika yang dialamatkan kepada Wali Kota Makassar Ramdhan Pomanto bahwa kota maju seperti Makassar sudah seharusnya berbasis eletronik. Di saat yang sama Gubernur Sulsel Sharul Yasin Limpo memuji walikota Makassar atas terbentuknya program tersebut pada acara Makassar City Ekspo, 3-5 Mei 2015. Dalam acara tersebut tidak lepas pula dengan pelepasan 100 ribu kartu smart city yang bisa digunakan untuk sejumlah transaksi seperti supermarket, parker, restoran, hotel, rumah sakit.

Dalam membentuk sebuah kota pintar bukanlah hal yang mudah. Membutuhkan smart plan yang baik, smart partner (mitra kerja yang produktif) serta dukungan masyarakat yang baik bisa menjadi dorongan terbentuknya program-program kreatif (smart people). Dalam memuluskan 
program smart city pemerintah Kota Makassar menggaet sejumlah pihak Microsoft Corp Public Sector ASEAN, Nusantara Infrastruktur, BRI, dan BTN dan PT. Telkom. PT. Telkom sendiri memang menargetkan bahwa 2014 adalah langkah awal untuk membentuk smart city di 20 kota termasuk Makassar dimana tujuanya adalah membentuk 'IT Enabler' sebagai resolusi kemajuan jaman menuju kota dunia. Oleh sebab itu pujian yang diberikan kepada Kota Makassar bukan hanya berhenti pada tingkat menteri dan gubernur tetapi juga Konsulat Jenderal (Konjen) Amerika, Joaquin Monserrate yang mengatakan bahwa Makassar sebagai kota pintar merupakan sebuah langkah maju untuk meneruskan pembangunan yang berkelanjutan danpelayanan yang cepat, tepat dan akurat dalam menjawab seluruh keluhan masyarakat dengan cepat tanggap.

\section{Peluang program smart city terhadap pertumbuhan Kota Makassar}

Reformasi birokrasi menjadi roh bergulirnya perubahan di Indonesia. Perubahan dari sentralisasi menjadi desentralisasi merupakan salah satu buah dari reformasi. Hadirnya otonomi daerah bisa menjadi peluang juga bisa menjadi hambatan berkembangnya suatu daerah. Lahirnya otonomi daerah memberikan kesempatan besar bagi daerah baik kabupaten maupun kota serta propinsi untuk melakukan hubungan luar negeri baik dalam bentuk kerjasama perdagangan, investasi mapun utang luar negeri. Sejalan dengan itu adanya globalisasi ekonomi melalui terciptanya Komunitas ASEAN menjadikan munculnya ekonomi baru di kawasan termasuk Indonesia. Tiga pilar Komunitas ASEAN yaitu politik dan keamanan, sosial dan budaya, serta ekonomi merupakan peluang besar bagi daerah untuk terjun langsung berkompetisi dalam menyambut terciptanya integrasi regional tersebut. Ada sejumlah peluang yang dihasilkan dari adanya program smart city di Makassar yakni menjadi kota dunia (global city), menjadi kota forum diplomasi internasional, melatih pejabat daerah dan beberapa aktor lain untuk menjadi diplomat (paradiplomasi), dan kesempatan kerjasama Sister City.

\section{Menjadi kota dunia (global city)}

Pada masa pemerintahan sebelumnya Makassar menginginkan menjadi salah satu 'kota dunia' yakni di masa pemerintahan Arif Sirajudin sebagai Walikota Makassar. Namun, realisasinya belum terwujud. Dengan adanya program smart city langkah Makassar bisa menjadi kota dunia dapat dengan mudah terealisasi. Beberapa faktor seperti transportasi, 
komunikasi, serta kota dagang pusat ekonomi di kawasan timur Indonesia menjadi faktor potensial untuk pengembangan Makassar dalam menciptakan kota yang lebih modern. Global city merupakan sebuah konsep yang menggambarkan transformasi ekonomi dunia yang modern dengan kemajuan teknologi informasi, penyebaran mobilitas barang dan jasa, likuiditas modal, tenaga kerja, bahan baku, wisatawan, telah melintasi batas-batas negara (Sassen, 2005). Deregulasi, privatisasi sistem hukum nasional yang mengizinkan masuknya perusahaan asing dalam kerjasama investasi asing tumbuh pesat dalam pasar global. Fenomena ini melahirkan artikulasi baru dalam sistem pemerintahan nasional suatu negara dengan terbentuknya sejumlah kota atau kabupaten sebagai sebuah sub-sistem nasional menjadi 'kota dunia'.

Saskia Sassen (2005:27-30) mengajukan sejumlah indikator terbentuknya 'kota dunia', yakni: pertama, letak geografis sangat berpengaruh terhadap proses globalisasi ekonomi yang secara simultan akan mempengaruhi kegiatan ekonomi yang dilakukan oleh perusahaan asing untuk mengelola, mengkordinasikan, memberikan pelayanan, jaringan operasi usaha terkait kerjasama investasi. Kedua, lokasi yang strategis sangat penting sebagai basis wilayah atau rumah produksi bagi sejumlah perusahaan asing untuk mengontrol usaha dan persaingan di pasar global. Ketiga, penyediaan bidang yang kompleks terutama bidangbidang produk yang bisa bersaing di pasar global. Artinya bidang yang akan dikembangkan dalam kota tersebut saling bersinergi antara bentuk pelayanan, tenaga ahli serta informasi pasar untuk memasarkan produk. Keempat, lokasi tersebut bisa mengembangkan produksi yang khas yang bisa menguntungkan perusahaan di pasar. Kelima, kota tersebut memiliki mitra kota strategis sebagai bentuk afiliasi kota transnasional yang digunakan untuk mencari peluang investasi asing dalam kegiatan ekonomi internasional. Keenam, dukungan profesional baik dalam bentuk atribut tata kelola kerja maupun admistrasi akan menciptakan industri manufaktur yang cenderung akan meningkat dan meminimalisir ketimpangan ekonomi sosial. Ketujuh, tingkat kestabilan ekonomi kota sangat penting dan efektif sebagai syarat untuk menjadi kota yang modern.

Indikator yang dikemukakan Saskia Sassen tersebut bisa ditemukan di kota Makassar. Kondisi ini terbukti dengan letak geografis Makassar yang sangat strategis yakni pintu gerbang di kawasan Indonesia timur yang sejak berabad-abad lalu telah menjadi salah satu pusat kota dagang di nusantara. Di samping itu, kondisi transportasi, komunikasi, 
serta teknologi yang memadai sudah bisa ditemukan di Makassar apalagi didukung oleh sistem budaya, tata krama pariwisata, dan kuliner menjadi daya tarik utama Makassar menuju kota yang lebih modern. Pertumbuhan ekonomi Makassar juga relatif stabil di kisaran 4-5 persen per tahun menjadi bukti nyata bahwa Makassar bisa dikembangkan menjadi pusat ekonomi kota modern di Indonesia. Sentuhan teknologi informasi (IT) yang lebih komprehensif akan menjadikan Makassar berkembang lebih dari sebelumnya.

Pelayanan yang berbasis IT ini jelas berdampak pada pelayanan masyarakat. Walikota Makassar menegaskan bahwa pelayanan masyarakat akan berbasis IT bahkan pengurusan hanya bisa lewat layanan pesan pendek (SMS) terutama pelayanan bidan, dokter dan admistrasi, pengurusan surat, e-bankingdan bentuk-bentuk pelayanan publik lainnya. Di luar itu, pengelolaan kota berbasis IT bisa mendukung fasilitas sarana dan prasarana kota. Pelayanan berbasis IT ini bisa dimanfaatkan sebagai e-diplomacy pemerintah daerah untuk mempromosikan potensinya melalui internet sejalan dengan program nasional untuk menciptakan pemerintahan berbasis elektronik atau $e$ government dan e-governance serta e-commarce.

Ketersediaan wifi merupakan salah satu infrastruktur smart city yang dapat dimanfaatkan oleh sejumlah pihak termasuk pengusaha dan kampus sebagai layanan untuk melayani pelanggannya. Ketersediaan jaringan internet bisa mendeteksi jalur jalan yang macet, serta membentuk masyarakat yang up to date terhadap informasi dari segala penjuru kota. Dengan demikian, smart city berpeluang menjadikan Makassar sebagai contoh bagi kota-kota lainnya di Indonesia. Jika internet berbasis seluler biasanya memiliki tingkat kecepatan akses yang rendah, maka dengan adanya wifi kecepatan akses bisa dua kali lipat lebih cepat sehingga disukai investor karena komunikasi yang lancar. Kondisi pertumbuhan ekonomi yang stabil dikisaran 5 persen ke atas juga menjadi pertimbangan investor untuk menciptakan basis ekonomi di kawasaan timur Indonesia sehingga bisa bersaing dengan kawasan barat Indonesia yang umumnya lebih maju.

Potensi lain yang menunjang pengembangan Makassar sebagai kota dunia adalah sektor pariwisata. Jumlah wisatawan asing yang berkunjung ke Makassar mengalami fluktuasi dari tahun ke tahun. Tabel di bawah ini menujukkan fluktuasi peningkatan jumlah wisatawan asing yang berkunjung ke Makassar sejak 2006 hingga 2010. Peningkatan tertinggi terjadi pada 2007 yaitu sebanyak 70,94 persen, sementara 
terendah terjadi pada 2010 yaitu 1,69 persen. Untuk menggenjot jumlah wisatawan asing, pemerintah daerah melakukan pembenahan infrastruktur. Sebagai contoh, infrastruktur Pantai Losari sudah semakin megah dengan adanya relokasi dan semakin asri, dan infrastruktur seperti hotel sudah memadai dengan desain yang modern. Selain wisata pantai, Makassar juga menghadirkan wisata relijius seperti masjid terapung yang menjadi salah satu tujuan wisata terbaru di Makassar. Dengan adanya program smart city promosi pariwisata dapat dilakukan secara lebih mudah.

Tabel 1 Fluktuasi jumlah wisatawan asing yang berkunjung ke Makassar sejak 2006 sampai 2010

\begin{tabular}{|l|l|l|l|}
\hline Tahun & $\begin{array}{l}\text { Wisatawan } \\
\text { Asing }\end{array}$ & $\begin{array}{l}\text { Presentasi } \\
\text { Peningkatan }\end{array}$ & PAD (RP) \\
\hline 2006 & 15.574 & $2,24 \%$ & 404.591 .500 \\
\hline 2007 & 19.785 & $70,94 \%$ & 298.647 .500 \\
\hline 2008 & 24,591 & $24,29 \%$ & 323.105 .000 \\
\hline 2009 & 28.233 & $14,77 \%$ & 434.392 .000 \\
\hline 2010 & 28.699 & $1,69 \%$ & 490.462 .000 \\
\hline
\end{tabular}

Sumber: Laporan Tahunan Dinas Kebudayaan dan Pariwisata Kota Makassar

Berdasarkan data di laman resmi Kota Makassar antara 14 November 2011 sampai dengan 27 November 2011, wisatawan asing yang berkunjung ke Makassar berasal dari sejumlah negara yakni Arab Saudi sebanyak 6 orang, Australia 7 orang, Belanda 15 orang, Hongkong 10 orang, Singapura 13 orang, Jepang 9 orang, Amerika Serikat 38 orang, dan Malaysia 153 orang (Wawancara dengan pengelola website Kota Makassar tanggal 20 Desember 2011). Dengan ketersediaan data statistik semacam itu, internet dapat bermanfaat sebagai alat pendukung smart city sebagai bahan informasi awal untuk mengetahui tentang Makassar. Sebab dengan mengetahui informasi awal tentang Makassar wisatawan asing akhirnya tertarik untuk berkunjung ke Makassar yang tentunya akan berimplikasi pada meningkatnya pendapatan daerah.

Investasi asing juga menjadi indikator penting kota dunia. Jumlah investasi asing di Makassar pada tahun 2007 mencapai angka US\$ 5,500,000, tahun 2008 US\$ 1,500,000 dan tahun 2009 US\$ 7,579,006. Namun, untuk dua tahun berikutnya yakni tahun 2010 dan 2011 jumlah 
investasi asing di Makassar menunjukan penurunan meskipun masih terbilang tinggi. Pada 2010 investasi asing di Makassar mencapai US\$ $1,200,000$. Investasi itu sebagian besar dialokasikan untuk sektor perdagangan digabungkan dengan restoran dan hotel mencapai persentase 30,12 persen dan sektor industri 20,46 persen serta sektor jasa sekitar 11,11 persen. (Fathun, 2012). Pada 2011 jumlah investasi asing mencapai US\$21,777,473,67 dengan jumlah areal tanah terpakai 2638,74 hektar. Pemerintah Kota Makassar mencoba memperbaiki regulasi, perpajakan dan sarana prasarana untuk kembali menarik minat investor untuk berinvestasi di Kota Makassar. Perkembangan investasi asing pada 2014 menurut Taufik Rahman mencapai US\$ 348 juta yang menyerap tenaga kerja sebanyak 300 orang di 56 perusahaan asing. Menggiatnya investasi di Makassar salah satunya disebabkan pemerintah daerah sudah menggunakan sistem pelayanan admistrasi berbasis online sehingga bisa menyelesaikan izin usaha hanya enam hari setelah persyaratan admistrasi dinyatakan lengkap. Kepala Bidang Penanaman Modal BPTPM Makassar, Momang Tisis menyebutkan jumlah investasi asing di Makassar sejak 2009 sampai 2014 mencapai US\$ 204 miliar. Investasi asing didominasi usaha di sektor perhotelan, kuliner dan industri.

Dalam menggiatkan masuknya investasi asing dibentuklah Makassar Investment Forum (MIF). Dalam diskusi tersebut Pemerintah Kota Makassar bersama sejumlah mitranya menginginkan Makassar menjadi Center Point di Indonesia, research university dan bahkan menjadi industrial park. Untuk itu dibutuhkan dana sekitar US\$2,35 miliar untuk membangun jalan tol, jalan umum sepanjang 40 kilometer, serta jalur kereta api Makassar menuju Pare-Pare. Sehingga, dengan program smart city ini diharapkan bisa menjadi 'mutiara' yang mengundang ketertarikan investor asing untuk menanamkan modalnya.

\section{Menjadi kota forum diplomasi internasional}

Makassar menjadi salah satu tuan rumah ASEAN Mayor Forum yang berlangsung pada 9-11 September 2015. Kegiatan ini adalah dibentuk oleh sejumlah negara-negara ASEAN untuk menyambut masyarakat ekonomi ASEAN yang akan mulai berlaku pada Desember 2015. Kegiatan ini merupakan forum diskusi insan muda, kreatif, akademisi, praktisi, LSM dan aktor lainya untuk menyiapakan Indonesia menuju Masyarakat Ekonomi ASEAN. Pembentukan Komunitas ASEAN sebelumnya direncanakan pada 2020 kemudian dimajukan pada 2015 untuk mempercepat integrasi antar sesama negara ASEAN. 
Adanya forum tersebut bisa menjadi agenda rutin baik pemerintah daerah untuk mencari solusi terbaik dalam mempersiapakan sumberdaya yang ada baik sumberdaya manusia maupun sumberdaya komoditas. Hal ini tentu saja bisa menjadi bagian diplomasi ekonomi untuk menarik investasi asing. Forum ini bisa menjadi agenda konsultasi terkait bagaimana mempersiapkan tiga pilar Komunitas ASEAN. Penyelenggaran pertemuan berskala internasional semacam ini bisa membuka peluang untuk pertemuan-pertemuan lainnya. Dengan dukungan smart city, smart people dan smart plan Makassar bisa menjadi salah satu center for international negotiation forum. Dengan basis kota modern Makassar bisa menjadi pilihan dalam menyelenggarakan pertemuan-pertemuan penting dalam hal diplomasi dan negosisasi. Dukungan infrastruktur seperti gedung CCC (Celebes Convenstion Center), karakter hotel berbintang lima seperti Grand Clarion atau tempat-tempat sejarah seperti Benteng Somba Opu atau Benteng Roterdam bisa menjadi pilihan untuk menyelenggarakan pertemuan-pertemuan diplomatik yang dapat menghapus kesan kaku diplomasi konvensional selama proses negosiasi.

Melatih pejabat daerah dan pemangku kepentingan menjadi diplomat (paradiplomasi)

Definisi diplomat konvensional saat ini mengalami pergeseran makna ke arah yang lebih non-konvensional. Pemerintah daerah dengan berbekal undang-undang otonomi daerah dan sejumlah aturan teknis dalam melakukan hubungan luar negeri dan kerjasama internasional menjadikan pemerintah daerah mampu berperan sebagai 'diplomat' yang memiliki kapasitas untuk memperjuangkan kepentingan daerah di ranah internasional. Selama ini diplomat-diplomat resmi terkesan sangat lamban dalam merespon kepentingan daerah apabila sejumlah investor asing ingin menanamkan modalnya sebab harus memasuki pintu Kementrian Luar Negeri terlebih dahulu. Untuk menangkap peluang yang ada, pemerintah daerah harus melakukan langkah 'potong kompas' dengan secara aktif melakukan hubungan luar negeri sesuai ketentuan undangundang.

Keberadaan internet dalam program smart city bisa menjadi instrumen politik pemerintah daerah untuk melakukan komunikasi melalui internet (e-diplomacy) maupun komunikasi secara langsung dalam hal pelayanan kepada wisatawan asing. Strategi ini bisa menjadi contoh kota-kota lainnya di Indonesia untuk mengembangkan kerjasama dengan 
pendekatan bottom up. Melalui e-diplomacy pemerintah daerah relatif mudah menarik investor asing dengan memperbaiki situs SKPD yang bisa dilihat langsung oleh sejumlah pengunjung. Terlebih lagi, Makassar telah lama dikenal sebagai kota dagang dan pariwisata. Dengan promosi $e$ diplomacy melalui halaman situs Pemerintah Kota Makassar dan SKPD setiap investor atau para pelancong sudah bisa melihat secara langsung kondisi geografis, latar belakang kota, peluang investasi, tempat wisata, keadaan politik dan hukum. Konsep smart city seperti ini merupakan jalan keluar di saat dunia semakin tanpa batas.

\section{Kesempatan kerjasama Sister City}

Peluang ini sangat potensial bagi Kota Makassar untuk menciptakan pertumbuhan ekonomi berkelanjutan. Sister city (kota kembar) bisa dilakukan dengan syarat adanya kesamaan budaya, visimisi, kota pariwisata dan kesamaan-kesamaan lainnya. Peluang ini sangat terbuka lebar bagi kota-kota yang ingin meningkatkan program smart city menjadi sister city. Strategi yang bisa ditempuh adalah mencari kota di beberapa negara yang berbasis IT untuk melakukan kerjasama saling menguntungkan tentang manfaat tata kelola kota berbasis IT. Untuk memudahkan dan memperlancar smart city tersebut maka pemerintah daerah harus menjalin kemitraan dengan kota di negara lain yang memiliki kemampuan teknologi informasi yang memadai.

Jepang merupakan salah satu negara yang bisa menjadi tujuan utama sister city Makassar misalnya dengan Tokyo atau Kyoto. Jepang sebagai negara dengan kapasitas teknologi informasi yang sangat maju bisa membagi pengetahuan dan pengalamannya kepada Makassar untuk memajukan ekonomi daerah dengan basis teknologi informasi. Peluang ini masih didukung dengan mahasiswa Jepang yang melakukan studi banding ke Makassar. Program pemerintah daerah seharusnya tidak berhenti pada smart city saja tetapi meningkatkannya menjadi kota kembar. Negara lain yang juga berpotensi adalah Amerika Serikat. Alasan utamanya adalah Konsulat Amerika Serikat sudah mengetahui tata ruang kota Makassar sehingga membuka peluang untuk ditindaklanjuti. Tulisan ini beranggapan bahwa program sister city sebaiknya ditindaklanjuti untuk menciptakan Makassar sebagai kota megaapolitan. Sister city bisa menciptakan 'aliansi', bukan aliansi antar negara melainkan antar kota, yang bertujuan mempercepat arus transformasi, akomodasi, dan komunikasi untuk mendukung ekonomi daerah yang potensial. Hal ini 
sangat berasalan mengingat Makassar sejak lama diklaim sebagai pusat kegiatan perekonomian Indonesia di kawasan timur.

\section{Kesimpulan}

Pergeseran orientasi diplomasi di era digital menjadikan perubahan dan bertambahnya aktor dan pelaku hubungan internasional. Perubahan pola hubungan internasional yang dilakukan oleh pemerintah pusat yang memberikan tanggung jawab kepada pemerintah daerah menjadikan sifat diplomasi bergeser dari konvensional yang bersifat sentralistik dan berkutat pada isu keamanan, politik dan kompetisi ekonomi yang tidak sehat ke non-konvensional yang lebih desentralistik dan inklusif. Transformasi diplomasi era digital oleh para aktor diplomasi selain negara membuka kesempatan bagi pemerintah daerah menjadi aktor diplomasi internasional. Perubahan tersebut disebabkan arus globalisasi yang mengaburkan batas-batas negara. Sekat antar negara tidak lagi menjadi hambatan untuk turut serta bermain dalam diplomasi digital.

Salah satu peran yang dimainkan oleh Pemerintah KotaMakassar sebagai aktor 'paradiplomasi' adalah menciptakan sebuah kota yang berbasis internet. Kota yang disebut smart city ini bertujuan untuk mendekatkan masyarakat pada pelayanan yang cepat dan tepat serta mudah dijangkau. Program strategis seperti smart city harus menjadi program utama bagi sejumlah daerah di Indonesia sebab era digital menuntut tata kelola pemerintahan yang berbasis pada e-government dan e-diplomacy sebagai usaha menciptakan pelayanan publik yang transparan, berintegritas, dan akuntabel untuk kemaslahatan bersama dan meminimalkan terjadinya korupsi dan fenomena 'raja-raja kecil' di daerah.

Praktek smart city di Makassar yang melibatkan para investor baik dari dalam negeri maupun luar negeri merupakan usaha Pemerintah Kota Makassar untuk menciptakan kota yang lebih modern. Adanya ketersediaan wifi gratis, CCTV, e-KTP, e-Office, e-restoran, e-karcis dan lain-lain merupakan langkah strategis menciptakan smart city. Dengan lokasi wilayah yang strategis didukung kota wisata, kota kuliner dan kota budaya menjadi daya tarik tersendiri bagi investor untuk menanamkan modalnya di Makassar. Alhasil, smart city merupakan variabel pengikat (daya tarik) untuk menarik masuknya investasi asing di bidang-bidang lainnya. Sedangkan smart city sendiri merupakan investasi dalam bentuk transfer teknologi yang di tujukan untuk menciptakan tata kelola pemerintahan yang lebih cepat, tepat, efisien, inovatif dan produktif. 
Kondisi-kondisi ini pada gilirannya dapat menciptakan kesejateraan yang lebih luas bagi masyarakat sekaligus memajukan perekonomian nasional.

\section{Daftar Pustaka}

Abidin, Z. P. (2007) Teknik Lobi dan Diplomasi: Untuk Insan Public Relations. Jakarta: PT. Indeks.

Arsyad, A. \& Masrie, A. (2010) Hubungan Luar Negeri Dalam Kerangka Otonomi Daerah (Studi Kasus: Provinsi Sulawesi Selatan) Makassar: Jurusan Politik Pemerintahan, Fakultas Ilmu Sosial dan Ilmu Politik, Universitas Hasanudin, pp.4.

David, C. (2008) Are The Boundaries Between Paradiplomacy and Diplomacy Watering Down. Belgium: University Of Anwerp and Flemish Centre for International Policy.

Djelantik, S. (2008) Diplomasi Antara Teori \& Praktek. Yogyakarta: Graha Ilmu.

Dougherty, J. E. \& Pfahzgraff, Jr, R.L. (1990) Contending Theories of International Relations: A comprehensive Suvey. New York: Third edition, Harper Collins Publisher, Inc.

Fathona, R.A. (2010) Mengoptimalkan Foreign Direct Investment ke Indonesia: Pelajaran dari Krisis Ekonomi Global 2008-2009, Jurnal Diplomasi, 2 (2) Jakarta: Pusat Pendidikan dan Pelatihan, Kementrian Luar Negeri, pp.163.

Fathun, L. M. (2012) Peluang dan Tantangan E-diplomacy dalam Menarik Investasi Asing di Kota Makassar. Maakassar: Universitas Hasanuddin.

Fatir, D. Smart City Makassar menjadi Konsep Kota ASEAN [Online], Antara News. Tersedia dalam: <http://m.antaranews.com/berita/452175/programsmart-city-makassar-diklaim-lebih-maju $\geq$ [Diakses 24 September 2015].

Imawan, R. (2006) Urgensi Politik Pembentukan/Pemekaran Daerah Otonom. Jurnal Ilmu Pemerintahan, 23 Masyarakat Ilmu Pemerintahan Indonesia, pp. 11.

Kartajaya, H. dan Yuswohady (2005) Attracting Tourist Traders Investors "Strategi Memasarkan Daerah Di Era Otonom". Jakarta: PT. Gramedia Pustaka Utama

Kuncoro, M. (1997) Ekonomi Pembangunan: Teori, Masalah dan Kebijakan. Yogyakarta: Unit Penerbit dan Percetakan Akademik Manajemen Perusahaan YPKN.

May, T. R. (2003) Hubungan Internasional Kontemporer dan Masalah-Masalah Global. Bandung: PT. Rafika Aditama.

Meerts, P. W. (2009) The Changing Nature of Diplomatic Negotiation: pp 90 dan lihat juga Stefan, W. Paradiplomacy: Scope, Opportunities and Challenges, University of Nottingham.

Melissen, J. (1999) Inovation in Diplomatic Practice. Newyork: St Matin's Press. 
Mukti, A.T. (2013) Paradiplomacy: Kerjasama Luar Negeri Oleh Pemda Di Indonesia. Yogyakarta: The Phinisi Press.

Nicolson, H. (1974) Diplomacy Ten and Now. Theory and Practice of International Relation, 2. New Jersey: Wiliam C Olson dan Fred A Soedarman, Prenticel Hall.

Rasyid, M. R. (1997) Kajian Awal Birokrasi Pemerintahan dan Politik Orde Baru. Jakarta: Yarsip Watampone.

Sassen, S. (2005) The Global City: Introducing A Concept. The Brown Journal World Affair, XI (2), Chicago: Piinccton University, pp.27-30.

Surwandono (2014) Menulis Demokrasi Indonesia. Yogyakarta: Percetakan Sahabat dan Jurusan Hubungan Internasional FISIPOL UMY.

Suryaningrat, B. (1981) Desentralisasi dan Dekonsentrasi Pemerintah di Indonesia Suatu Analisa. Jakarta: Dewa Ruci Press.

Todaro, M. P. (1994) Pembangunan Ekonomi di Dunia Ketiga Jilid I. Jakarta: Erlangga. 